Linguistik Terapan 18 (2) (2021): 149 - 161

Jurnal Linguistik Terapan Pascasarjana

Available online

http://jurnal.unimed.ac.id/2019/index.php/JLT-Unimed

\title{
DEVELOPING ENGLISH TEACHING MATERIALS FOR YOUNG LEARNERS BASED ON ISLAMIC VALUES OF INTEGRATED LANGUAGE SKILLS FOR ISLAMIC ELEMENTARY SCHOOL
}

\author{
Savitri Rahmadany \\ Rahmad Husein \\ Masitowarni Siregar \\ English Applied Linguistics Program \\ Postgraduate Program-Universitas Negeri Medan
}

\begin{abstract}
This Research and Development (R\&D) is conducted to develop English teaching materials for young learners of grade four based on Islamic values of integrated language skills at SD IT AL Hijrah 2 Deli Serdang. The objectives of this study are 1) to analyze English teaching materials are needed by the students, 2) to develop the English teaching materials, and 3) to give reasons for the English teaching materials developed. The respondent of this study is 23 respondents which consisted of twenty (20) fourth-grade students, one (1) English teacher, and two (2) lecturers. The data is collected by questionnaire, interview, and documentary. The results of this study showed that 1) English teaching materials needed by the students are English teaching materials based on Islamic values of integrated language skills, 2) the development of English teaching materials were developed through four steps, namely evaluation and need analysis, material development, material validation, and revision and final product, and 3) the reason English teaching materials are developed based on Islamic values of integrated language skills is because of the Islamic elementary schools and the terms or level of young learners. Based on the expert's judgment result, the score was 3.68, and the percentage is $90 \%$ categorized as very good. It means that the developed materials were relevant or appropriate for the fourth-grade students of Islamic elementary school. It implies that the teacher can use the developed English teaching materials based on Islamic values of integrated language skills and Islamic elementary needs to lead the students to learn English in the Islamic context.
\end{abstract}

Keywords: Research and Development (R\&D), Teaching Materials for Young Learners, Islamic Values of Integrated Language Skills, Islamic Elementary School

How To Cite: Rahmadany, Savitri. (2021). Developing English Teaching Materials for Young Learners based on Islamic Values of Integrated Language Skills for Islamic Elementary School. Jurnal Linguistik Terapan-Pascasarjana Unimed. 18 (2): 149 - 161. 


\section{INTRODUCTION}

English is one of the foreign languages taught in Indonesia even from kindergarten to senior high school. Although in elementary schools English is a local content subject most schools teach English. Brewster, Ellis, and Girrard (2002) state that it is important to teach English earlier to young learners because it increases the total number of years spent in learning the language. It has been widely accepted that teaching English to young learners gains more attention, whether from parents, teachers, or stakeholders. They believe that it gives more benefits. They also rely on the assumption that the sooner they teach English to children, the better the result would be.

Children like studying something new. One of them is the study of language. It is implied that young learners who learn English earlier are hoped to comprehend English earlier too so that in the future it can be useful not only in education but also in other fields. Some scholars, on the other hand, argue that it only gives more burdens to the learners. Shin (2012) states that early start alone will not necessarily improve children's ability to learn English. Thus, early English language teaching in children does not guarantee that they will prevail against it.

Teachers need to understand who young learners are. They are children who are learning English. As novice learners, surely they do not receive the same treatment as teen or adult learners. They have their special characteristics. Theimplication for English teaching and learning, the learning process should be planned, implemented, assessed, and supervised by the conditions of the learners.

In learning English, four skills should be mastered by the students (Suyanto, 2014). They are listening, speaking, reading, and writing. They are important and interconnected with each other. Considering the age, listening and speaking are the skills that young language learners need to master first. Through these skills, the learners can recognize what the speaker says and how to express their ideas.

On the other hand, teaching English to young learners in Indonesia is quite problematic since English has limited practice in the 2013 curriculum (UU No. 20, 2003). English is not included in the curriculum. Although it is omitted from the curriculum, English is not banned. The schools may give English as an extracurricular subject. This class can be after school for about one hour. Even so, there is still a possibility for schools that want to add English as an additional subject in their curriculum. One of them is the Islamic Elementary School of Al-Hijrah 2 Deli Serdang. They realized that English is important to be taught earlier and useful in the future. They made their syllabus. 
SDIT Al-Hijrah 2 Deli Serdang is one of the Islamic elementary schools which has Islamic teaching as its special characteristics. The vision is "Being an excellent school in spiritual, emotional, and intellectual also care of the environment". Based on its vision, SDIT Al-Hijrah 2's education goal is developing students who are muttaqien (pious) with intelligence, noble characters, and life skills that are useful for many people. Furthermore, JSIT-Jaringan Sekolah Islam Terpadu (2014) states integrated Islamic elementary schools are Islamic schools that offer some knowledge with the Islamic values into the subjects. Therefore, this school tries to fuse the national education curriculum with religious values. The fuse of the curriculum is done by integrating Islamic values into all the subjects including English subjects.

Moreover, integrating Islamic values is not easy because English for children is different from English for adults. Cameron (2001) states that children have a short concentration in their learning when compared to adults. They are also more easily distracted by other typical learners. For these reasons, teachers in elementary schools need to understand the children's needs and apply the theories by their characteristics. The teachers also should provide the existing materials that are sure for their students' needs.

However, some problems appear in the teaching and learning process. Based on the observation by interviewing the English teacher at the Islamic elementary school Al-Hijrah 2 Deli Serdang, the teacher stated that they do not have any special books related to materials for teaching English to young learners in Islamic Elementary Schools. They still use general English as teaching and learning materials which is not by the learning needs of students in Islamic Elementary School. The themes or images contained in the teaching and learning materials also are not Islamic either. The teacher only inserts the Islamic foundation into each material being taught. Teachers often feel that the available textbooks are not sufficient to achieve the various objectives associated with language teaching.

Also, learning activities were lack. The teacher did not provide variations in the activities. The activities are not challenging enough for young learners' students. The teaching materials only consist of some activities in every unit. There is almost no variation in exercise activity in each unit. For example, in listening skills, in each unit, students are only asked to listen and repeat the sentences after the teacher says them. Students need a variety of activities according to their needs so that the teaching and learning process can run smoothly. In the learning process, the teacher had taught based on the syllabus. The topic is by the syllabus. 
Materials take an important part in the teaching and learning process. Materials are included in anything which can be used to facilitate the learning of a language. They can be textbook, module, LKS (students' worksheet), document, handout, or media, and can be presented in printing form, live performance, and display on cassette, CD-ROM, DVD, or the internet (Tomlinson, 2000). It is not difficult to find out or access the materials for the elementary level at the book store. But most teachers use the materials directly without editing or adjusting base on the students' needs, and some of the materials do not contain Islamic values. It should be adapted to the students' material development as well. So, material development is everything made by people (the writer, the teacher, or the learners) to give and utilize information and provide an experience of the user of language, which is design to fulfill the learners' needs and consider the objective of the learning. The teacher should develop the materials by adapting them to improve or to make them more suitable to learners' needs.

Grave (2000) states a study about material development is the planning process by which a teacher can put the objectives and goals of the course into units and tasks. Developing materials is necessary to provide more resources to the learners. With more resources, learners can receive better results in learning the language. In developing materials, developers must consider some important points such as selecting the topics of the materials and activities. Those points must be conducted in proper order.

Some studies have discussed material development. One of the studies was written by Khoiriyah and Widyantoro (2018). The study discussed integrated skills materials for the students of Islamic elementary school consisted of integrated skills activities and some Islamic values in every unit. The materials were developed for third-grade students. However, another grade of students will possibly different related to teaching materials. Another study discussed by Cahyo, Muslim, Rahman, and Pratolo (2019) focused on developing Islamic English teaching material that is necessary to achieve the national education goal and for the Islamic faith itself. It was based on Akhlak (moral, ethic) specified for the reading skill of the teaching materials. Thus, it can be said that this study specified Islamic materials in reading skills. Even though, the skills of English materials for elementary students are integrated. Then, a study carried out by Rahman, Masnayadi, Nerim, and Muslim (2018) showed an English textbook consists of four major skills of English like listening, speaking, reading, and writing. This study utilized a scientific approach in the 2013 Curriculum. But, not all schools, especially elementary schools, apply this curriculum.

Based on this fact, this study expected to solve the problems stated previously by 
developing English teaching materials for young learners for Islamic elementary schools. Also, the English teaching materials will be designed for fourth-grade students based on Islamic values of integrated language skills of KTSP (school based-curriculum). There are consists of four skills such as reading, speaking, writing, and listening skills.

Thus, those phenomena show that there are limited English teaching materials that incorporate Islamic values. Therefore, this study is interested in developing English teaching materials for young learners based on Islamic values of integrated language skills for Islamic elementary schools that meet the students' needs.

In relation to the background of the study the objectives of the study are:

1. To analyze English teaching materials are needed by the fourth-grade students for young learners based on Islamic values of integrated language skills for Islamic elementary school of AL Hijrah 2 Deli Serdang.

2. To develop the English teaching materials of the fourth-grade students for young learners based on Islamic values of integrated language skills for Islamic elementary school of AL Hijrah 2 Deli Serdang.

3. To give reasons for the English teaching materials of the fourth-grade students for young learners based on Islamic values of integrated language skills for Islamic elementary school of AL Hijrah 2 Deli Serdang developments.

\section{METHODOLOGY}

Research design of this study was Research and Development (R \& D) model by Borg and Gall (2003) which consist of a set of steps to develop or design new educational product. The writer chose this research process aim to develop a quality product design to meet the specific teaching materials that can be used at elementary school.

\section{FINDINGS AND DISCUSSIONS}

The research findings refer to research question of the studyto develop English teaching materials for young learners of grade four based on Islamic values of integrated language skills at SD IT AL Hijrah 2 Deli Serdang. The first question is "what English teaching materials are needed?" The second question is "How are the English teaching materials developed?"And the third question is "why are the English teaching materials developed in the ways they are". Based on the data analysis was found the result as explanation below 


\section{A. English Teaching Materials Needed}

Table 1. Students' Needs Analysis of English Teaching Materials

\begin{tabular}{|c|c|c|c|c|c|}
\hline No. & Questions & Options & $\mathbf{N}$ & $\mathbf{F}$ & $\begin{array}{c}\text { Percentages } \\
(\%) \\
\end{array}$ \\
\hline \multirow[t]{5}{*}{1.} & \multirow{5}{*}{$\begin{array}{l}\text { What English-based } \\
\text { teaching materials do } \\
\text { you need? }\end{array}$} & a. Islam & 20 & 20 & 100 \\
\hline & & b. America & 20 & 0 & 0 \\
\hline & & c. English & 20 & 0 & 0 \\
\hline & & d. Australia & 20 & 0 & 0 \\
\hline & & e. Indonesia & 20 & 0 & 0 \\
\hline \multirow[t]{5}{*}{2.} & \multirow{5}{*}{$\begin{array}{l}\text { In your opinion, what } \\
\text { topics do you need in } \\
\text { Islamic-based } \\
\text { English teaching } \\
\text { materials? }\end{array}$} & a. Human relationship with God & 20 & 4 & 20 \\
\hline & & b. Human-human relations & 20 & 3 & 15 \\
\hline & & c. Akhlatul Kharimah & 20 & 12 & 60 \\
\hline & & d. Nature/environment & 20 & 1 & 5 \\
\hline & & e. Others, (write down)... & 20 & 0 & 0 \\
\hline \multirow[t]{5}{*}{3.} & $\begin{array}{l}\text { In your opinion, how } \\
\text { the material in }\end{array}$ & $\begin{array}{l}\text { a. By basic competencies and } \\
\text { competency standards }\end{array}$ & 20 & 0 & 0 \\
\hline & \multirow{4}{*}{$\begin{array}{l}\text { English teaching } \\
\text { materials for Islamic- } \\
\text { based schools should } \\
\text { be better? }\end{array}$} & $\begin{array}{l}\text { b. Authentic material / that can be } \\
\text { found in everyday life }\end{array}$ & 20 & 2 & 10 \\
\hline & & c. Material with Islamic concepts & 20 & 8 & 40 \\
\hline & & $\begin{array}{l}\text { d. The presentation and } \\
\text { explanation of the material are } \\
\text { clear }\end{array}$ & 20 & 10 & 50 \\
\hline & & e. All are correct & 20 & 0 & 0 \\
\hline
\end{tabular}

The data in table 1 are about the necessities of the students about English teaching materials. There were $100 \%$ students need teaching materials based on Islam to learn English. For the topic, there were $20 \%$ students need a human relationship with God, $15 \%$ students need human and human relations, 60\% students need Akhlatul Karimah, and 5\% students need nature/environment as the topic in the English teaching materials. For the materials, there were $10 \%$ students need authentic material that can be found in everyday life, $40 \%$ students need a material with Islamic concepts, and 50\% students need the material presented and explained clearly in the English teaching material for Islamic elementary school.

Table 2. Students' Needs Analysis of English Teaching Materials

\begin{tabular}{lllccc}
\hline No. & \multicolumn{1}{c}{ Questions } & \multicolumn{1}{c}{ Options } & N & $\begin{array}{c}\text { Percentages } \\
(\%)\end{array}$ \\
\hline 4. & How good is the & a. Very good & 20 & 0 & 0 \\
& English teaching & b. Good & 20 & 8 & 40 \\
& materials used in SD & c. Enough & 20 & 1 & 5 \\
& IT AL Hijrah 2? & d. Less & 20 & 11 & 55 \\
& & e. Very less & 20 & 0 & 0 \\
5. & How do you & a. Very understand & 20 & 0 & 0 \\
& understand English & b. Understand & 20 & 4 & 20 \\
& teaching materials? & c. Sufficiently understand & 20 & 6 & 30 \\
& & d. Not really understand & 20 & 9 & 45 \\
6. & What difficulties did & a. I don't understand the material & 20 & 1 & 5 \\
& you face when & in the teaching material & & & 25 \\
& mastering the & b. I am not interested and feel & 20 & 1 & 5 \\
& material on English & bored regarding the teaching & & & \\
\hline
\end{tabular}




\begin{tabular}{|c|c|c|c|c|c|}
\hline No. & Questions & Options & $\mathbf{N}$ & $\mathbf{F}$ & $\begin{array}{c}\text { Percentages } \\
(\%)\end{array}$ \\
\hline & teaching materials? & materials provided & & & \\
\hline & & $\begin{array}{l}\text { c. Teaching materials do not make } \\
\text { students active }\end{array}$ & 20 & 4 & 20 \\
\hline & & $\begin{array}{l}\text { d. The material seems } \\
\text { monotonous }\end{array}$ & 20 & 2 & 10 \\
\hline & & e. All are correct & 20 & 8 & 40 \\
\hline
\end{tabular}

The data in table 2 are about the lack of the students about English teaching materials. For the lack of materials used, there were $40 \%$ students said were good, 5\% students said were enough, and $55 \%$ students said were less. For the understanding, there were $40 \%$ students understand, 30\%students had sufficiently understood, $45 \%$ students still have less understand, and 5\% students not understood at all about English teaching materials. For the difficulties faced by the students, there were $25 \%$ students did not understand, $5 \%$ students did not interest and get bored, 20\% students said the English teaching materials do not make them active, $10 \%$ students said the English teaching material seems monotonous for them, and $40 \%$ students said all of the choices were the factors they hardly understood about English teaching materials.

Table 3. Students' Needs Analysis of English Teaching Materials

\begin{tabular}{|c|c|c|c|c|c|}
\hline No. & Questions & Options & $\mathbf{N}$ & $\mathbf{F}$ & $\begin{array}{c}\text { Percentages } \\
(\%)\end{array}$ \\
\hline \multirow[t]{5}{*}{7.} & \multirow{5}{*}{$\begin{array}{l}\text { In your opinion, which } \\
\text { skills are a priority in } \\
\text { English teaching } \\
\text { materials in integrated } \\
\text { Islamic elementary } \\
\text { schools? }\end{array}$} & a. Listening & 20 & 3 & 15 \\
\hline & & b. Speaking & 20 & 1 & 5 \\
\hline & & c. Writing & 20 & 1 & 5 \\
\hline & & d. Reading & 20 & 2 & 10 \\
\hline & & e. All are correct & 20 & 13 & 65 \\
\hline \multirow[t]{5}{*}{8.} & In your opinion, how the & a. Interesting & 20 & 2 & 10 \\
\hline & layout/arrangement of & b. Cleanly & 20 & 4 & 20 \\
\hline & Islamic-based English & c. Can motivate me to learn & 20 & 6 & 30 \\
\hline & teaching materials should & d. $\mathrm{a}, \mathrm{b}$, and $\mathrm{c}$ are correct & 20 & 8 & 40 \\
\hline & be? & e. Others, (write down)... & 20 & 0 & 0 \\
\hline \multirow[t]{5}{*}{9.} & $\begin{array}{l}\text { In terms of appearance I } \\
\text { want English language }\end{array}$ & $\begin{array}{l}\text { a. In it, there are many } \\
\text { pictures }\end{array}$ & 20 & 5 & 25 \\
\hline & teaching materials that ... & $\begin{array}{l}\text { b. In it, there are many } \\
\text { exercises }\end{array}$ & 20 & 3 & 15 \\
\hline & & $\begin{array}{l}\text { c. Only presents material to be } \\
\text { studied }\end{array}$ & 20 & 0 & 0 \\
\hline & & $\begin{array}{l}\text { d. Has an attractive } \\
\text { appearance and color } \\
\text { (colorful) }\end{array}$ & 20 & 12 & 60 \\
\hline & & e. Others (write down).... & 20 & 0 & 0 \\
\hline
\end{tabular}

The data in table 3 are about the wants of the students about English teaching materials. For the skills, there were $15 \%$ students want listening skill, 5\% students want speaking skill, 5\% students want writing skill, and 65\% students wants all of the skills as the priority in the English teaching materials. For the layout, there were $10 \%$ students want an 
interesting English teaching materials, 20\% students want the English teaching materials cleanly, $30 \%$ students want that can motivate them to learn, and $40 \%$ students said all of the choices were the arrangements should be in English teaching materials. In terms of appearance, there were $25 \%$ students want there are many pictures inside, $15 \%$ students want there are many exercises inside, and $60 \%$ students wants the English teaching materials that has an attractive appearance and colorful.

Table 4. Students' Needs Analysis of English Teaching Materials

\begin{tabular}{|c|c|c|c|c|c|}
\hline No. & Questions & Options & $\mathbf{N}$ & $\mathbf{F}$ & $\begin{array}{c}\text { Percentages } \\
(\%)\end{array}$ \\
\hline \multirow[t]{5}{*}{10.} & $\begin{array}{l}\text { In general, Islamic } \\
\text { English teaching }\end{array}$ & $\begin{array}{l}\text { a. Recognizing English words } \\
\text { (parts of speech) }\end{array}$ & 20 & 5 & 25 \\
\hline & $\begin{array}{l}\text { materials should be able } \\
\text { to make me ... }\end{array}$ & $\begin{array}{l}\text { b. Use English words to } \\
\text { communicate }\end{array}$ & 20 & 7 & 35 \\
\hline & & $\begin{array}{l}\text { c. Understand the meaning of } \\
\text { words in English }\end{array}$ & 20 & 5 & 25 \\
\hline & & $\begin{array}{l}\text { d. Able to write vocabulary in } \\
\text { English correctly }\end{array}$ & 20 & 3 & 15 \\
\hline & & e. Others, (write down)... & 20 & 0 & 0 \\
\hline
\end{tabular}

The data in table 4 are about the goal of the students about English teaching materials. There were 25\% students recognize English words (parts of speech), 35\% students use English words to communicate, $25 \%$ students to understand the meaning of words in English, and $15 \%$ students to be able to write vocabulary in English correctly as they goal in learning the English teaching material.

Table 5. Students' Needs Analysis of English Teaching Materials

\begin{tabular}{lllccc}
\hline No. & \multicolumn{1}{c}{ Questions } & \multicolumn{1}{c}{ Options } & N & F & $\begin{array}{c}\text { Percentages } \\
(\mathbf{\%})\end{array}$ \\
\hline 11. & In your opinion, is there a & a. It is necessary & 20 & 12 & 60 \\
& need for an integrated & b. Need & 20 & 5 & 25 \\
image display by the & c. Sometimes it is necessary & 20 & 3 & 15 \\
Islamic basis in English & d. No need & 20 & 0 & 0 \\
teaching materials? & e. Unnecessary & 20 & 0 & 0 \\
\hline
\end{tabular}

The data in table 5 are about the input of the students about English teaching materials. There were $60 \%$ students said for add Islamic-based picture, 25\% students said Islamic-based picture it is a need, and $15 \%$ students said it is necessary for add Islamic-based picture in English teaching materials.

Table 6. Students' Needs Analysis of English Teaching Materials

\begin{tabular}{llllcc}
\hline No. & \multicolumn{1}{c}{ Questions } & Options & N & F & $\begin{array}{c}\text { Percentages } \\
(\%)\end{array}$ \\
\hline 12. & $\begin{array}{l}\text { In your opinion, the English } \\
\text { teaching and learning process } \\
\text { should take place ... }\end{array}$ & a. $\begin{array}{l}\text { By the learning } \\
\text { objectives }\end{array}$ & 20 & 1 & 5 \\
& b. Participative \\
156 & 20 & 3 & 15
\end{tabular}




\begin{tabular}{llllc}
\hline No. Questions & \multicolumn{1}{c}{ Options } & N & F & $\begin{array}{c}\text { Percentages } \\
(\boldsymbol{\%})\end{array}$ \\
\hline & \begin{tabular}{l} 
c. $\begin{array}{l}\text { Easy to } \\
\text { follow/understand }\end{array}$ \\
\cline { 2 - 5 }
\end{tabular} & 20 & 16 & 80 \\
\cline { 2 - 6 } & $\begin{array}{l}\text { d. By the development of } \\
\text { students }\end{array}$ & 20 & 0 & 0 \\
& e. Others, (write down)... & 20 & 0 & 0 \\
\hline
\end{tabular}

The data in table 6 are about the procedures of the students about English teaching materials. There were $5 \%$ studentssaid should by the learning objectives, $15 \%$ studentssaid should participative, $80 \%$ studentssaid English teaching and learning process should easy to follow/understand.

Table 7. Students' Needs Analysis of English Teaching Materials

\begin{tabular}{llllcc}
\hline No. & \multicolumn{1}{c}{ Questions } & \multicolumn{1}{c}{ Options } & N & F & $\begin{array}{c}\text { Percentages } \\
(\%)\end{array}$ \\
\hline 13. & I prefer if the assignment & a. All students & 20 & 0 & 0 \\
& system in English & b. Individual & 20 & 5 & 25 \\
& teaching materials is & c. Group & 20 & 8 & 40 \\
& done in a ... & d. Couple & 20 & 7 & 35 \\
& e. Others, (write down)... & 20 & 0 & 0 \\
\hline
\end{tabular}

The data in table 7 are about the setting of the students about English teaching materials. There were $25 \%$ preferred the assignment system done individually, $40 \%$ students preferred done in a group, $35 \%$ students preferred done in pairs.

Table 8. Students' Needs Analysis of English Teaching Materials

\begin{tabular}{|c|c|c|c|c|c|}
\hline No. & Questions & Options & $\mathbf{N}$ & $\mathbf{F}$ & $\begin{array}{c}\text { Percentages } \\
(\%)\end{array}$ \\
\hline \multirow[t]{5}{*}{14.} & \multirow{5}{*}{$\begin{array}{l}\text { In the process of } \\
\text { delivering English } \\
\text { teaching materials } \\
\text { you should ... }\end{array}$} & $\begin{array}{l}\text { a. Just listen to the explanation of } \\
\text { the material }\end{array}$ & 20 & 4 & 20 \\
\hline & & b. Record all material submitted & 20 & 7 & 35 \\
\hline & & $\begin{array}{l}\text { c. Participate actively in the } \\
\text { learning process }\end{array}$ & 20 & 9 & 45 \\
\hline & & $\begin{array}{l}\text { d. Learn by yourself and work on } \\
\text { the problems calmly }\end{array}$ & 20 & 0 & 0 \\
\hline & & e. Others, (write down)... & 20 & 0 & 0 \\
\hline
\end{tabular}

The data in table 8 are about the learners' role of the students in English teaching materials. There were $20 \%$ students preferred to just listen to the explanation, $35 \%$ students said preferred to write all English teaching materials presented, 45\%studentssaid they participate actively in the learning process.

Table 9. Students' Needs Analysis of English Teaching Materials

\begin{tabular}{lllllc}
\hline No. & \multicolumn{1}{c}{ Questions } & \multicolumn{1}{c}{ Options } & N & $\begin{array}{c}\text { Percentages } \\
(\%)\end{array}$ \\
\hline 15. & $\begin{array}{l}\text { In the process of } \\
\text { delivering English } \\
\text { teaching materials, } \\
\text { the teacher should... }\end{array}$ & $\begin{array}{l}\text { a. } \\
\text { b. } \begin{array}{l}\text { Explain and ask students to do } \\
\text { practice questions } \\
\text { Read the material and interpret } \\
\text { it directly with students }\end{array}\end{array}$ & 20 & 10 & 50 \\
\hline
\end{tabular}




\begin{tabular}{llllc}
\hline No. Questions & \multicolumn{1}{c}{ Options } & N & F & $\begin{array}{c}\text { Percentages } \\
(\mathbf{\%})\end{array}$ \\
\hline & c. $\begin{array}{l}\text { Circling the class while } \\
\text { controlling student work and } \\
\text { making comments }\end{array}$ & 20 & 2 & 10 \\
& d. $\begin{array}{ll}\text { Guide students in discussing } \\
\text { material }\end{array}$ & 20 & 2 & 10 \\
& e. Others (write down) ... & 20 & 0 & 0 \\
\hline
\end{tabular}

The data in table 9 are about the teachers' role of the students in English teaching materials. There were $50 \%$ studentspreferred the teacher to explain and ask students to do practice questions, $30 \%$ studentspreferred the teacher to read the material and interpret it directly, $10 \%$ studentspreferred the teacher to circle the class while controlling student work and making comments, and $10 \%$ studentspreferred the teacher to guide them in discussing the English teaching material

The students need analysis also collected by interview with English teachers. The teacher agreed to integrate the Islamic values into Islamic English teaching Materials. She said that the basic core of Islamic Elementary School is the integration of Islamic values into all subjects including English. Such as the values of Tawheed, Muamalah, and Akhlakul Karimah. By the basis of Islamic schools, that is what we teach first and which we emphasize the most. So in everyday life children can apply and reflect these values.

Based on the result of interview can be conclude thatthe English book used by the school did not contain Islamic values yet. It was still a general English book with general values and pictures. There was not a special book for SDIT with their special characteristics. So, they need English teaching materials for Islamic elementary schools.

\section{B. The Developed English Teaching Materials}

Based on the result of student's need analysis, then the researcher designing syllabus and English teaching materials based on Islamic values of integrated language skills of Islamic elementary school. The syllabus is used as the guideline in developing English teaching materials for Islamic elementary school. The syllabus consists of the unit title, objectives, core material, a language skill, activities, Islamic values, assessment, time allocation, and media/sources.

The materials in this study consist of seven units. Those units were developed by using learning sequences. They are:

1. My Friends and I

2. Food and Drinks 

3. My home
4. Times
5. In the School
6. It Looks Good
7. Hobbies

There were fourteen activities include reflection, Islamic corner, and glossary for each unit. The activities developed based on integrated skills (listening, reading, speaking, and writing). The figure describes the parts of each unit of the materials (Irvani, 2019).

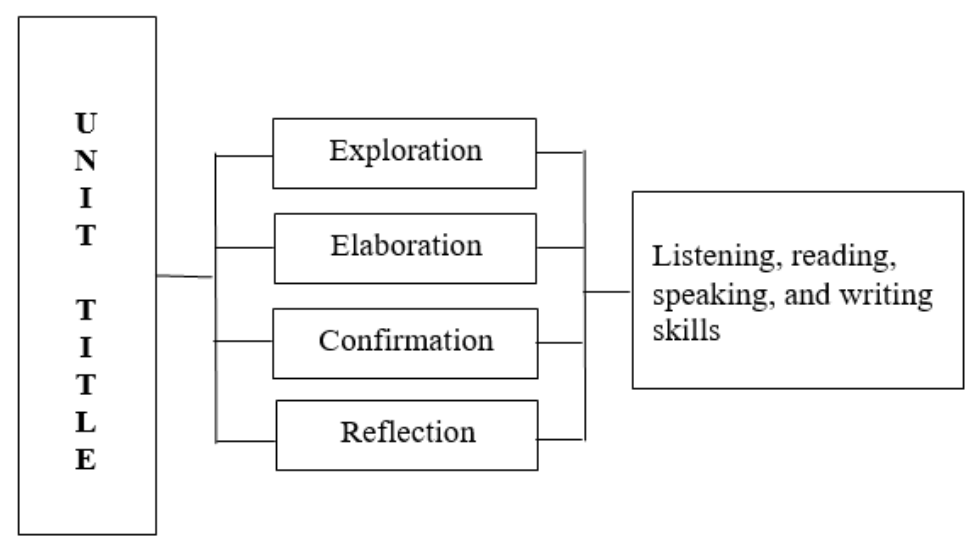

After that, the English teaching materials was validated. The average is 3.68 and the percentage is $90 \%$. It means the product in the level of feasibility categorized as very good. The English teaching materials were appropriate to be used by the fourth-grade students of SD IT AL Hijrah 2 Deli Serdang.

\section{The Reasons for Developing English Teaching Materials}

There are some reasons why the English teaching materials for Islamic elementaryschools are based on integrated language skills developed.

From the results of interviews with the English teacher, it was found that the English teacher was agreed to develop the English teaching materials with the Islamic values. Also, the language skills should be integrated that included listening, reading, speaking, and writing skills.

Islamic elementary school is a part of the Integrated Islamic School Network (JSITJaringan Sekolah Islam Terpadu). It is Islamic schools that offer some knowledge with the integration of Islamic values into the subjects. The values are not only in the religion subject but also in all the subjects taught to the students. One of them is an English subject. Also, it supports the result of students' needs. The necessities of the students' need with a percentage of 
$100 \%$ showed that they agreed English teaching materials based on Islam are used to learn English. It means the English teaching materials based on Islamic values are what the learners should know or achieve to functions effectively in the target situation. By integrating the Islamic values hope will lead the students to learn the subjects in the Islamic context.

Moreover, in terms of young learners, the substance of language skills of English lessons that the students learn is integrated, not separated from each other (the government through a policy numbered 19 in 2005). There are listening, speaking, reading, and writing skills. Also, it supports the result of students' needs. The wants of the students' need with a percentage of $65 \%$ showed the students agreed that all of the skills such as listening, speaking, writing, and reading as the priority in the English teaching materials. It means those skills that they want to master and become the priority in English teaching and learning in Islamic elementary schools.

\section{CONCLUSSION}

English teaching materials are needed by the students are Islamic English teaching materials based on Islamic values of integrated language skills. The English teaching materials should easy to follow/understand, has an attractive appearance and color (colorful), and used an Islamic-based picture. The English teaching materials also should make the students use English words to communicate as the goal and participate actively in the teaching and learning process.

The English teaching materials were developed through four steps, namely; (1) evaluation of the existing materials, syllabus, and need analysis; (2) material development based on Islamic values of integrated language skills for Islamic elementary school; (3) new English teaching material validation; and (4) revision and final product of the new English teaching materials. There was consist of seven units, namely, My Friends and I, Food and Drinks, My home, Times, In the School, It Looks Good, and Hobbies. The English teaching materials developed base on Islamic values of integrated language skills. The theme is developed with an Islamic values/context. The developed English teaching materials were categorized as very good and relevant to the Islamic elementary school with the average is 3.68 and the percentage is $90 \%$.

The reason why the English teaching materials for young learners based on Islamic value of integrated language skills for Islamic elementary school are developed because Islamic elementary school as a part of the Integrated Islamic School Network (JSIT-Jaringan Sekolah Islam Terpadu) and in the terms or level of young learners (EYL). 


\section{REFERENCES}

Brewster, J., G. Ellis, and D. Girard. (2002). The Primary English Teacher's Guide (2nded). London: Penguin Books.

Borg, W. R., and Gall, M.D. (1983). Educational Research. $4^{\text {th }} e d$. New York: Longman Inc.

Hutchinson, Tom, and Alan Waters, (1987). English for Specific Purposes: Alearning centred approach. Cambridge: Cambridge University.

Cahyo, S. P., M. R. U. Muslim, A. N. Rahman, and B. W. Pratolo. (2019). Need Analysis of Islamic-based English Reading Material for the Muhammadiyah Junior High School. International Journal of Evaluation and Research in Education (IJERE), Vol. 8, No. 2, pp. 286-292.

Cameron, L. (2001). Teaching Language to Young Learners. Cambridge: Cambridge University Press.

Graves, K. (2000). Designing Language Courses: A Guide for Teachers. Boston: Heinle \& Heinle Publisher.

Hyo Kim, (2013). Needs Analysis for ESP course Development for Engineering Students in Korea. International. Journal of Multimedia and Ubiquitous Engineering.Kongju National University, Korea.

Irvani, N. (2019). Developing Islamic English Learning Materials for Teaching English to Young Learners in the Integrated Islamic Elementary School. FBS, Universitas Negeri Yogyakarta, Yogyakarta.

JSIT Indonesia. (2014). Standar Mutu Kekhasan Sekolah Islam Terpadu. Jakarta: Jaringan Sekolah Islam Terpadu.

Khoiriyah, K. and A. Widyantoro. (2018). Design of Integrated Skills Materials for Islamic School. International Journal of Multicultural and Multireligious Understanding, Vol. 5, Issue 5, pp. 1-10.

Nunan, D. (2006). Principles for Designing Language Teaching Materials. $8^{\text {th }}$ Edition. Guidelines, Vol. 10, No. 2, pp 1-24.

Rahman, A., Masnayadi, Nerim, and Muslim. (2018). Developing English Materials based on Scientific Approach through Content for Islamic Senior High School Students. Journal of Languages and Language Teaching, Vol. 6, No. 2, pp. 86-95.

Shin, J. K. (2012). Teaching English to Young Learners. Baltimore Country: University of Maryland.

Suyanto, K.K.E. (2008). English for Young Learners. Jakarta: PT Bumi Aksara.

Tomlinson, B. (2012). Materials Development in Language Teaching. Cambridge: Cambridge University Press.

Widdowson, H. G. (1978). Teaching Language as Communication. Oxford: Oxford University Press. 